\title{
Correction of Zinc Deficiency in Pecan by Soil Banding
}

\author{
Bruce W. Wood ${ }^{1}$ \\ U.S. Department of Agriculture, Agricultural Research Service, Southeastern \\ Fruit and Tree Nut Research Laboratory, 21 Dunbar Road, Byron, GA \\ 31008-0087
}

Additional index words. Carya illinoinensis, nutrient disorder, stress, growth, micronutrients, sulfate, oxide

\begin{abstract}
Zinc (Zn) deficiency is common in commercial pecan [Carya illinoinensis (Wangenh.) C. Koch] orchards. Correction by multiple annual foliar spray applications is expensive but effective in eliminating $\mathrm{Zn}$ deficiency. Correction by soil application is also expensive and is usually impractical or noneffective. There is a need for more economical and long-lasting methods for satisfying tree $\mathrm{Zn}$ nutritional needs. It is reported here that tree foliar $\mathrm{Zn}$ needs [(i.e., $50 \mu \mathrm{g} \cdot \mathrm{g}^{-1}$ dry weight (dw) or greater] are potentially met through one-time "banding" of $\mathrm{Zn}$ sulfate $\left(\mathrm{ZnSO}_{4} \cdot 7 \mathrm{H}_{2} \mathrm{O}\right)$ or $\mathrm{Zn}$ oxide ( $\mathrm{ZnO})$ onto orchard floors. Zinc needs of 4-year-old 'Desirable' trees growing on acidic soil were satisfied over a 4-year period by a single-banded soil application of either $\mathrm{Zn}$ sulfate or $\mathrm{ZnO}$ over underground drip irrigation lines at a $\mathrm{Zn}$ rate of $2112 \mathrm{~g} \mathrm{Zn}$ per tree (giving foliar $\mathrm{Zn}$ concentrations of $60-115 \mu \mathrm{g} \cdot \mathrm{g}^{-1} \mathrm{dw}$ ). Rates of $\mathrm{Zn}$ at 264 to $1056 \mathrm{~g}$ per tree are occasionally efficacious, but rates less than $264 \mathrm{~g} \mathrm{Zn}$ per tree $(0,33,66$, and 132) were always ineffective for meeting a leaf sufficiency threshold of $50 \mu \mathrm{g} \cdot \mathrm{g}^{-1} \mathrm{dw}$. Sulfate and oxide $\mathrm{Zn}$ forms were equally effective in meeting tree $\mathrm{Zn}$ needs. Foliar $\mathrm{Zn}$ concentrations increased quadratically with increasing soil-banded $\mathrm{Zn}$ treatments; however, foliar $\mathrm{Zn}$ concentrations did not necessarily increase over the 4-year period within each $\mathrm{Zn}$ rate treatment. Increasing amounts of banded $\mathrm{Zn}$ per tree also increased foliar Mn concentration (from $\approx 150$ to $269 \mu \mathrm{g} \cdot \mathrm{g}^{-1} \mathrm{dw}$ ) of treated trees the fourth year posttreatment but did not affect foliar concentration of other key micronutrients (i.e., Fe, $\mathrm{Co}, \mathrm{Cu}$, or $\mathrm{Ni}$ ). This fertilization strategy offers an efficacious alternative to annual foliar Zn sprays for orchards established on acidic soils and provides a means of ensuring rapid and long-term $\mathrm{Zn}$ absorption through soil application. The approach indicates that soil banding of $\mathrm{Zn}$ on certain acidic soils can satisfy the nutritional needs of pecan trees for several years after a single application.
\end{abstract}

Pecan is a zinc (Zn)-sensitive species possessing a relatively high $\mathrm{Zn}$ requirement (Sparks, 1987; Swietlik, 1999). Zinc deficiency is a common, and often major, problem in commercial pecan orchards, especially those established on sandy well-drained acidic soils and on soils from phosphatic rocks. Deficiency is common in the acidic soils of the southeastern United States and the high $\mathrm{pH}$, calcareous soils of the southwestern United States. There has therefore been extensive research, spanning several decades, on methods for correction of $\mathrm{Zn}$ deficiency in pecan (Alban, 1955; Alban and Hammar, 1941, 1944; Banin et al., 1980; Harper, 1960; Payne and Sparks, 1982; Sparks, 1976; Worley et al., 1980). Tree and orchard $\mathrm{Zn}$-related requirements are potentially met through several early spring foliar sprays each year (Smith et al., 1979) by broadcast application of relatively large amounts of $\mathrm{Zn}$ fertilizers to soils (Brooks, 1964) or by trunk implants or injection (Worley et al., 1980).

Received for publication 11 May 2007. Accepted for publication 24 June 2007.

${ }^{1}$ To whom reprint requests should be addressed; e-mail bwwood@saa.ars.usda.gov. enough to substantially offset $\mathrm{Zn}$ needs by growing organs the following spring (Walworth and Pond, 2006). The cost of foliar applications is considerable, whether through ground rigs or from aircraft, and is far greater than the cost of the $\mathrm{Zn}$ material being applied. This cost, plus timely access to trees in flood-irrigated orchards, is problematic for pecan producers.

Correction of $\mathrm{Zn}$ deficiency problems by soil application is potentially advantageous in that the approach can provide trees with available $\mathrm{Zn}$ for several years, whereas foliar sprays generally correct deficiency in the season of application (Brooks, 1964; Hunter, 1965; Payne and Sparks, 1982; Wood and Payne, 1987). Ground application options include 1) broadcasting, 2) banding, or 3) trenching. Broadcast application (over the entire orchard floor or only beneath the tree canopy) typically requires 23 to $114 \mathrm{~kg}$ (50 to $250 \mathrm{lbs}$ ) $\mathrm{Zn}$ sulfate per acre; in addition, the first 2 to 3 years (depending on tree and orchard situation) after the ground application may still result in the need for foliar sprays. Application through trenching, even in acidic soils, is generally inferior to broadcast applications, although it can be efficacious and practical (Smith et al., 1934). Problems with satisfactory uptake, expense, or both is problematic for commercial operations applying $\mathrm{Zn}$ through broadcast ground application. Banding $\mathrm{Zn}$ in a wide band within the perimeter of the canopy dripline potentially reduces the amount of $\mathrm{Zn}$ required; however, commercial operations rarely adopt the approach. Success at preventing $\mathrm{Zn}$ deficiency by soil application (broadcast and trenching) is erratic and variable among southeast regional orchards and is almost never effective in high-pH southwestern orchards (Walworth and Pond, 2006). Thus, soil application as a means of correction of $\mathrm{Zn}$ deficiency remains problematic for commercial-scale orchard operations. Soil $\mathrm{Zn}$ application strategies, although potentially efficacious, are unpopular in the southeastern United States where acidic soils are typical and are essentially absent from operations in calcareous alkaline southwestern U.S. soils where efficacy is problematic.

The potential long-term efficacy of a single soil application makes the approach especially attractive if there is a concurrent reduction in the amount of $\mathrm{Zn}$ fertilizer needed to satisfy tree needs. The present soil application rate for southeastern soils is typically 2.27 to $4.54 \mathrm{~kg} \mathrm{Zn}$ sulfate per tree (Brooks, 1964). The most recent study of the banding approach concluded that narrow banding was potentially inferior to broadcasting beneath the tree canopy in that it did not correct $\mathrm{Zn}$ deficiency as quickly as broadcasting relatively large amounts of $\mathrm{Zn}$ (Payne and Sparks, 1982). This approach used $\mathrm{Zn}$ sulfate rates up to $3.2 \mathrm{~kg}$ of $\mathrm{Zn}$ per tree dispersed in a $15-\mathrm{cm}$-wide band encircling nonirrigated trees positioned in the middle of a 14.2-m diameter circle. The use of drip irrigation technology in southeastern U.S. pecan orchards has proliferated since the 
1982 study; thus, the situation exists in which tree $\mathrm{Zn}$ needs might potentially be more efficiently satisfied by using a more concentrated band in close physical association with irrigation emitters. Additionally, a cost squeeze affecting most farmers reflects a need to reduce production costs. Adoption of a one-time approach to $\mathrm{Zn}$ fertilizer application, possible reduction of the amount of $\mathrm{Zn}$ used in orchards, and use of the most economical efficacious $\mathrm{Zn}$ sources collectively offer potential for a long-term reduction in production costs as well as better tree $\mathrm{Zn}$ nutrition. Additionally, because whole-tree $\mathrm{Zn}$ nutrition is likely best satisfied through soil application, there is a need for development of efficacious techniques for supplying $\mathrm{Zn}$ through the soil (Swietlik, 1999).

Zinc sulfate has traditionally been the preferred source for correction of deficiency through soil application on acidic soils (O'Barr, 1989). This is because of its relatively high water solubility $\left(1.67 \mathrm{~g} \cdot \mathrm{mL}^{-1}\right.$ $\mathrm{H}_{2} \mathrm{O}$ ), indirect source of sulfur (S), and ease of use (Worley et al., 1972). Conversely, Zn oxide is generally a more economical source per unit, or mole, of $\mathrm{Zn}$; yet, it has exceedingly low water solubility (less than 0.00001 $\mathrm{g} \cdot \mathrm{mL}^{-1} \mathrm{H}_{2} \mathrm{O}$ ). This solubility differential is likely of little practical significance, because most ground-applied $\mathrm{Zn}$ sulfate eventually converts to $\mathrm{Zn}$ oxide in soils (Viets, 1962), thus largely neutralizing a perceived advantage of $\mathrm{Zn}$ sulfate over $\mathrm{Zn}$ oxide in orchards. A study of a wide variety of $\mathrm{Zn}$-sensitive agronomic and horticultural crops concludes that $\mathrm{Zn}$ oxide is at least as good as $\mathrm{Zn}$ sulfate in correcting $\mathrm{Zn}$ deficiency (Murphy and Walsh, 1972). Worley et al. (1972) came to the same conclusion for pecan after comparing the ability of several $\mathrm{Zn}$ sources for correcting foliar deficiencies. However, after more than three decades since Worley's report, $\mathrm{Zn}$ sulfate remains the overwhelmingly used source by the southeastern U.S. pecan industry. Because $\mathrm{Zn}$ oxide is usually a more economical source per unit of $\mathrm{Zn}$ than $\mathrm{Zn}$ sulfate, and appears to be as effective as $\mathrm{Zn}$ sulfate for correcting deficiency through broadcast soil applications, there is a need to compare the efficacy of these two $\mathrm{Zn}$ sources when applied as a highly concentrated band to soils supporting orchard trees. This study assesses the efficacy of correcting $\mathrm{Zn}$ deficiency of young drip-irrigated pecan orchards on an acidic mineral southeastern U.S. soil using a single concentrated band of either $\mathrm{Zn}$ oxide or $\mathrm{Zn}$ sulfate applied over drip irrigation emitters.

\section{Materials and Methods}

Orchard and soil situation. The study orchard is comprised of 'Desirable' trees grafted to open-pollinated 'Elliott' rootstocks and is located at Byron, GA (lat. 32 $39^{\prime} 54^{\prime \prime} \mathrm{N}$, long. $83^{\circ} 44^{\prime} 31^{\prime \prime} \mathrm{W}$ ). Trees are spaced $9.1 \mathrm{~m}$ between rows and $4.6 \mathrm{~m}$ within rows. The experimental orchard soil is a Faceville fine sandy loam (FoA; fine, kaolinotic, thermic Typic Kandiudult). Belowground drip irrigation lines with drip emitters rising to the soil surface at 1-m intervals along the line provide trees with supplemental water. Parallel irrigation lines run the length of tree rows positioned $1.2 \mathrm{~m}$ on either side of trunks. Drip emitters delivered water at a rate of 3.78 $\mathrm{L}$ per hour, for $\approx 8$ to $12 \mathrm{~h}$ per day, depending on water needs throughout the growing season. The irrigation lines were within an herbicide strip maintained in a bare state using glyphosate.

Trees were entering their fourth year of growth at the time of the initiation of the study. Table 1 presents general soil characteristics of the orchard site. In general, the soil is typical of many southeastern U.S. soils and therefore many regional pecan orchards. The orchard received uniform annual broadcast soil applications of nitrogen, phosphorus, and potassium, calcium, and magnesium based on University of Georgia Extension Service recommendations; however, trees did not receive ground or foliar applications of $\mathrm{Zn}$ and other trace elements during the study period.

Zinc treatments. Trees within the previously described 'Desirable' orchard exhibited moderate Zn-deficiency symptoms beginning the third growing season after orchard establishment with deficiency exhibited by control trees in all subsequent years. This orchard was therefore used to evaluate the potential for correction of deficiency through application of either $\mathrm{Zn}$ sulfate $\left(\mathrm{ZnSO}_{4} \cdot 7 \mathrm{H}_{2} \mathrm{O}\right)$ or $\mathrm{Zn}$ oxide $(\mathrm{ZnO})$ as a concentrated band of $\mathrm{Zn}$ fertilizer placed in a 10 $\mathrm{cm} \times 4$-m band exactly over the drip irrigation lines on each side of the trees. $\mathrm{Zn}$ application treatments were at equivalent rates of actual $\mathrm{Zn}$, for each of the $\mathrm{Zn}$ sulfate and $\mathrm{ZnO}$ sources, over a concentration range of $0,33,66,132,264,528,1056,2112$, and $4224 \mathrm{~g}$ of actual $\mathrm{Zn}$ per tree. Treatments were established as a randomized complete block (RCB) consisting of four blocks. The experimental unit was comprised of single trees separated from neighboring trees by at least one tree or by a tree row. The concentrated band treatments were applied to soils in mid Mar. 2003. The experiment was a factorial consisting of two-factors $\left(\mathrm{ZnSO}_{4} \cdot 7 \mathrm{H}_{2} \mathrm{O}\right.$ versus $\mathrm{ZnO}$ ) at nine levels ( $\mathrm{g} \mathrm{Zn}$ per tree) structured as a RCB with foliage annually analyzed for $\mathrm{Zn}$ concentration over the following four growing seasons.

Foliar analysis. Leaf $\mathrm{Zn}$ concentration was determined annually from 2003 through 2006 from leaf samples collected from individual trees in late July by standard sampling methods with samples collected from all four cardinal directions of the midcanopy. Individual samples were rinsed according to Smith and Storey (1976), oven-dried at $55{ }^{\circ} \mathrm{C}$ to a constant weight, ground, and stored in airtight containers until analysis. Samples $[0.5 \mathrm{~g}$ dry weight $(\mathrm{dw})]$ were ashed at $500{ }^{\circ} \mathrm{C}$, dissolved in $20 \%$ nitric acid (TraceSelect; Sigma-Aldrich, St. Louis), and diluted with $2 \%$ nitric acid to $50 \mathrm{~mL}$. Aliquots were then appropriately diluted and analyzed for $\mathrm{Zn}$ using a PerkinElmer ELAN 9000 ICP-Mass Spectrometer (Concord, Ontario, Canada) interfaced with a CETEC ASX-510 Autosampler (CETEC Technologies, Omaha, NE) through monitoring of the $\mathrm{Zn}^{67}$ mass $[4 \%$ natural abundance (n.a.)]. Additionally, foliage sample analysis of individual trees during the fourth growing season enabled assessment of the influence of $\mathrm{Zn}$ treatments on key trace metals by monitoring the following masses: $\mathrm{Ni}^{60}$ (26\% n.a.), $\mathrm{Cu}^{63}(69 \%$ n.a.), $\mathrm{Fe}^{57}$ ( $2 \%$ n.a.), $\mathrm{Mn}^{55}$ (100\% n.a.), and $\mathrm{Co}^{59}$ (4\% n.a.).

Data analysis. All differences among treatment effects compounded throughout the experimental periods (all years after treatment); thus, analysis was by repeated measures and multivariate analysis of variance using JMP (JMP-SAS, Cary, NC). Additionally, because of the need to assess treatment effects yearly, effects were analyzed by "year" (for each year separately) using analysis of variance (ANOVA) and Student-Newman-Keuls test using JMP. ANOVA analysis using standard least squares was based on the previously described factorial design and performed for each year. The alpha level for all statistical tests was $\leq 0.05$.

\section{Results and Discussion}

Repeated-measures analysis using the Wilks' lambda test indicated differences in foliar $\mathrm{Zn}$ concentration based on "year" $(P<0.0001)$, "year*block" $(P<0.0075)$, "zinc rate" $(P<0.00001)$, and "year* $\mathrm{Zn}$

Table 1. Soil characteristics of a Desirable pecan orchard before implementation of the present study involving application of zinc through a narrow concentrated band to the orchard floor over drip-irrigation lines on each side of trees.

\begin{tabular}{|c|c|c|c|c|c|c|c|c|c|c|c|c|}
\hline $\begin{array}{l}\text { Soil } \\
\text { depth }(\mathrm{cm})\end{array}$ & $\mathrm{pH}$ & $\begin{array}{c}\text { CEC } \\
(\mathrm{meq} / 100 \mathrm{~g})\end{array}$ & $\begin{array}{c}\mathrm{P} \\
\left(\mathrm{kg} \cdot \mathrm{ha}^{-1}\right)\end{array}$ & $\begin{array}{c}\mathrm{K} \\
\left(\mathrm{kg} \cdot \mathrm{ha}^{-1}\right)\end{array}$ & $\begin{array}{c}\mathrm{Mg} \\
\left(\mathrm{kg} \cdot \mathrm{ha}^{-1}\right)\end{array}$ & $\begin{array}{c}\mathrm{Ca} \\
\left(\mathrm{kg} \cdot \mathrm{ha}^{-1}\right)\end{array}$ & $\begin{array}{c}\mathrm{B} \\
\left(\mathrm{kg} \cdot \mathrm{ha}^{-1}\right)\end{array}$ & $\begin{array}{c}\mathrm{Zn} \\
\left(\mathrm{kg} \cdot \mathrm{ha}^{-1}\right)\end{array}$ & $\begin{array}{c}\mathrm{Mn} \\
\left(\mathrm{kg} \cdot \mathrm{ha}^{-1}\right)\end{array}$ & $\begin{array}{c}\mathrm{Fe} \\
\left(\mathrm{kg} \cdot \mathrm{ha}^{-1}\right)\end{array}$ & $\begin{array}{c}\mathrm{Cu} \\
\left(\mathrm{kg} \cdot \mathrm{ha}^{-1}\right)\end{array}$ & $\begin{array}{c}\mathrm{Ni} \\
\left(\mathrm{kg} \cdot \mathrm{ha}^{-1}\right)\end{array}$ \\
\hline $2.6-5.1$ & 5.1 & 6.6 & $43 \mathrm{~L}$ & $300 \mathrm{H}$ & $179 \mathrm{~A}$ & $893 \mathrm{~A}$ & $0.9 \mathrm{M}$ & $9 \mathrm{~A}$ & $109 \mathrm{VH}$ & $19 \mathrm{~A}$ & $0.7 \mathrm{~L}$ & 0.9 \\
\hline $5.2-10.2$ & 5.8 & 5.5 & $27 \mathrm{~L}$ & $300 \mathrm{~A}$ & $162 \mathrm{~A}$ & $833 \mathrm{~A}$ & $0.8 \mathrm{M}$ & $3.2 \mathrm{~L}$ & $85 \mathrm{VH}$ & $20 \mathrm{~A}$ & $0.7 \mathrm{~L}$ & 0.7 \\
\hline
\end{tabular}

${ }^{\mathrm{z}}$ According to Georgia Extension Service recommendations: $\mathrm{L}=$ low; $\mathrm{M}=$ medium; $\mathrm{A}=$ adequate; $\mathrm{H}=$ high; $\mathrm{VH}=$ very high.

$\mathrm{CEC}=$ cation exchange capacity (i.e., total number of negative charge available to attract positively charged ions in solution). 
source*Zn rate" $(P<0.0272)$. Subsequent ANOVA analysis by "year" provided the following model characteristics: For 2003, model $\mathrm{R}^{2}=0.74$ with a "Zn rate" effect at $P<0.0001$; for 2004 , model $\mathrm{R}^{2}=0.74$, with a "Zn rate" effect at $P<0.0001$; for 2005 , model $\mathrm{R}^{2}=0.81$, with a " $\mathrm{Zn}$ rate" effect at $P<0.0001$; and for 2006, model $\mathrm{R}^{2}=0.83$, with a "Zn rate" effect at $P<0.0001$. Because " $Z n$ source" and the " $Z n$ source* $Z n$ rate" interaction are not significant, and for the purpose of clarity, data are combined regarding " $\mathrm{Zn}$ source" and plotted for " $\mathrm{Zn}$ rate" for each "year" with mean separation by Tukey's honestly significant difference (HSD) test (Fig. 1). ANOVA analysis of Mn concentration in foliage, during the fourth year posttreatment (i.e., 2006), provided the following model characteristics: model $\mathrm{R}^{2}=$ 0.92 , with " $Z$ n source" effect at $P<0.0001$, "Zn rate" at $P<0.0001$, and at $P<0.0001$. Manganese means for the " $\mathrm{Zn}$ source* $\mathrm{Zn}$ rate" effect, as separation by Tukey's HSD test, is presented in Figure 2.

The $\mathrm{Zn}$ concentration in 'Desirable' foliage increased proportionally as the amount of soil-banded $\mathrm{Zn}$ increased (Fig. 1). This increase occurred in these 'Desirable' trees within 4 months after application (Fig. 1A). The absence of a "year* $\mathrm{Zn}$ source" interaction $(P=0.69)$ is evidence that the relatively poor water solubility of $\mathrm{ZnO}$ (less than $0.00001 \mathrm{~g} \cdot \mathrm{mL}^{-1} \mathrm{H}_{2} \mathrm{O}$ ) did not pose a significant disadvantage with regard to $\mathrm{Zn}$ uptake by pecan from this particular acidic soil situation. Conversely, $\mathrm{ZnSO}_{4} \cdot 7 \mathrm{H}_{2} \mathrm{O}$ possesses relatively high water solubility $\left(1.67 \mathrm{~g} \cdot \mathrm{mL}^{-1} \mathrm{H}_{2} \mathrm{O}\right)$, being greater than $10^{5}$-fold greater. Thus, under conditions of this study, the relatively insoluble $\mathrm{ZnO}$ is as effective during the first 4 years as is soluble $\mathrm{ZnSO}_{4} \cdot 7 \mathrm{H}_{2} \mathrm{O}$ in satisfying foliar tree needs. The increase in foliar $\mathrm{Zn}$ concentration during the first growing season, as a consequence of increasing amounts of soilbanded $\mathrm{Zn}$ per tree, reflected both linear and curvilinear relationships; however, the relationship best approximates a quadratic $[f(x)=$ $\left.y 0+\mathrm{a} x+\mathrm{b} x^{2}\right]$ polynomial. Thus, foliar $\mathrm{Zn}$ concentration increased curvilinearly in a quadratic manner $(y=29.05+0.040 x-$ $\left.0.00000517 x^{2} ; \mathrm{R}^{2}=0.65 ; P \leq 0.0001\right)$, resulting in maximum foliar $\mathrm{Zn}$ concentration at $\approx 115 \mu \mathrm{g} \cdot \mathrm{g}^{-1} \mathrm{dw}$. Midsummer $\mathrm{Zn}$ concentration in foliage of nontreated trees was $\approx 20 \mu \mathrm{g} \cdot \mathrm{g}^{-1} \mathrm{dw}$ with foliage exhibiting typical visual symptoms of $\mathrm{Zn}$ deficiency. The generally accepted Zn sufficiency level of $50 \mu \mathrm{g} \cdot \mathrm{g}^{-1} \mathrm{dw}$ (Sparks and Payne, 1982) was achieved during the first year of application by either the sulfate or oxide sources applied at a rate $528 \mathrm{~g} \mathrm{Zn}$ or greater per tree (Fig. 1A) with foliage of trees treated with these treatments being free of visual $\mathrm{Zn}$ deficiency symptoms. The highest $\mathrm{Zn}$ treatment of $4224 \mathrm{~g} \mathrm{Zn}$ per tree elevated foliar $\mathrm{Zn}$ concentration to $\approx 115 \mu \mathrm{g} \cdot \mathrm{g}^{-1} \mathrm{dw}$ during the first year after application.

During the second posttreatment growing season (2004), the early season was very dry and the irrigation system failed. Thus, the
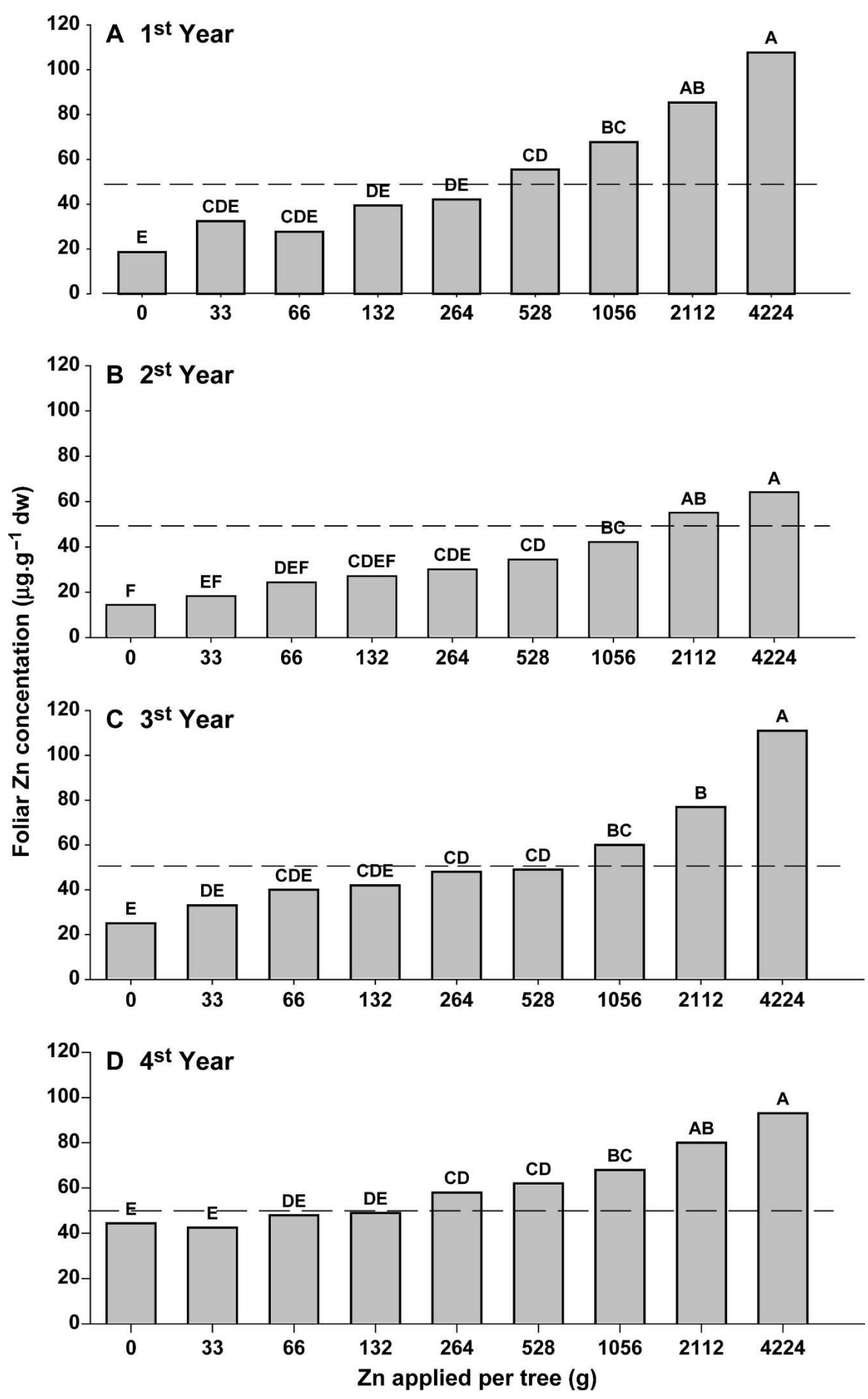

Fig. 1. Leaflet zinc $(\mathrm{Zn})$ concentrations of 'Desirable' pecan trees in response to a single soil application of $\mathrm{Zn}$ as a concentrated band over drip-irrigation lines on each side of the trees. Zinc was applied Mar. 2003. Foliar Zn concentrations reflect Zn present in foliage in late July 2003 and each July of for 3 years afterward. Treatment means with different letters are statistically significant by Tukey's honestly significant difference test at $a=0.05$. The horizontal dashed line is the standard extension service recommendation of $50 \mu \mathrm{g} \cdot \mathrm{g}^{-1}$ dry weight for whole-canopy leaf $\mathrm{Zn}$ concentration.

drier soil conditions required banded $\mathrm{Zn}$ at $2112 \mathrm{~g}$ or greater per tree to exceed the $50 \mu \mathrm{g} \cdot \mathrm{g}^{-1} \mathrm{dw}$ sufficiency threshold, this being a fourfold greater amount of $\mathrm{Zn}$ than was required under more normal soil moisture circumstances. During this dry spring, the high $4224 \mathrm{~g}$ per tree $\mathrm{Zn}$ rate treatment elevated foliar $\mathrm{Zn}$ to only $\approx 63 \mu \mathrm{g} \cdot \mathrm{g}^{-1} \mathrm{dw}$, with the untreated control being $\approx 16 \mu \mathrm{g} \cdot \mathrm{g}^{-1}$ $\mathrm{dw}$ (Fig. 1B). Zinc concentration in foliage quadratically increased $(y=20.5+0.0240 x$ $\left.-0.00000324 x^{2} ; \mathrm{R}^{2}=0.68 ; P \leq 0.0001\right)$ as the amount of soil-applied $\mathrm{Zn}$ increased. A much greater amount of banded $\mathrm{Zn}$ was therefore required to satisfy tree needs when soil moisture was more limiting.

"Zn rate" was the only significant $(P<$ $0.0001)$ treatment effect in either the third or 


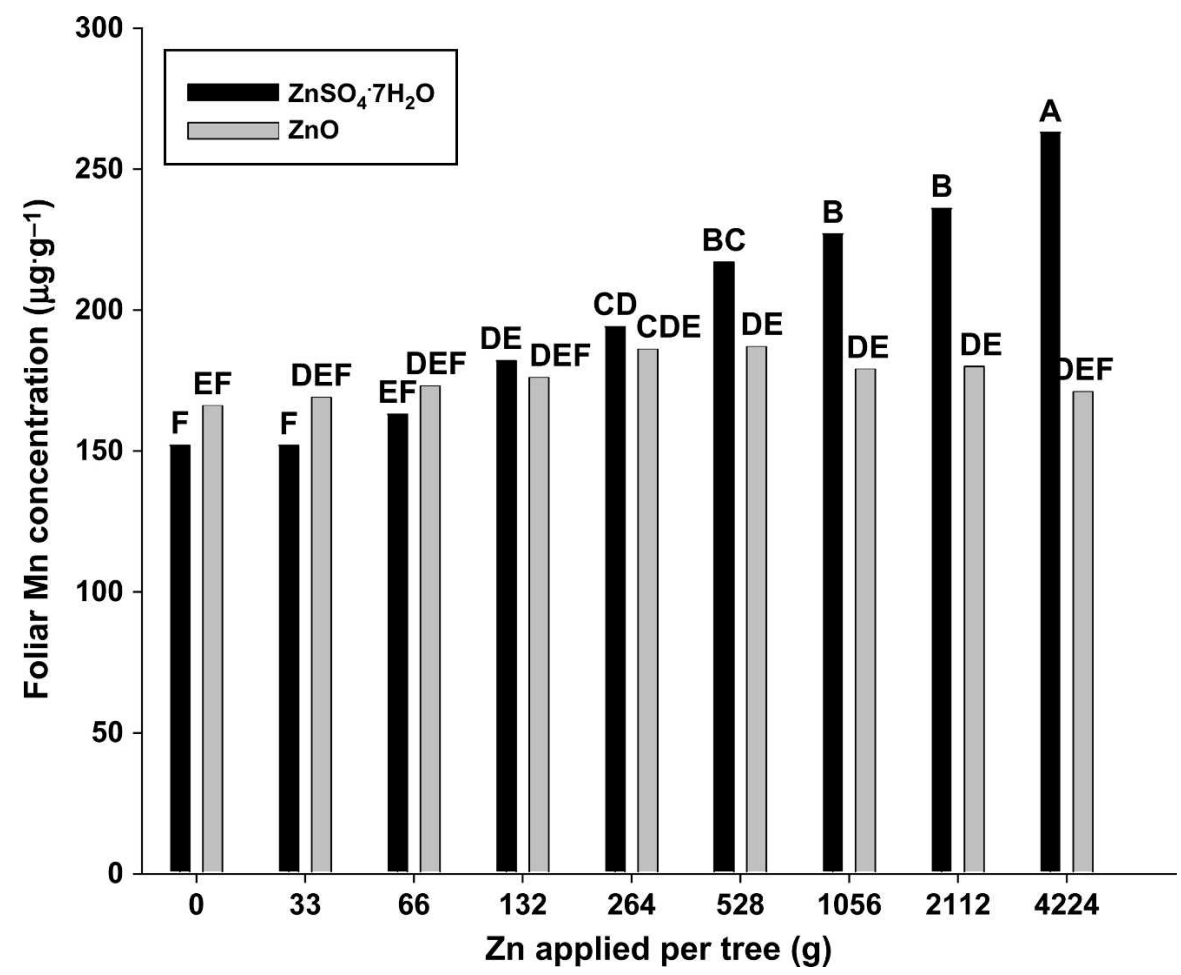

Fig. 2. Influence of soil-banded zinc $(\mathrm{Zn})$ treatments from $\mathrm{ZnSO}_{4} \cdot 7 \mathrm{H}_{2} \mathrm{O}$ and $\mathrm{Zn}$ oxide sources on foliar Mn concentration the fourth year after $\mathrm{Zn}$ application. Treatment means with different letters are statistically significant by Tukey's honestly significant difference test at $a=0.05$.

fourth growing season. Thus, this banding approach to $\mathrm{Zn}$ fertilization resulted in tree $\mathrm{Zn}$ needs being satisfied for at least 4 years after application (Fig. 1). The critical Zn threshold for foliage was satisfied during the third growing season by the $1056 \mathrm{~g}$ or greater $\mathrm{Zn}$ per tree treatment applied 3 years earlier (Fig. 1C), whereas the threshold during the fourth growing season was satisfied by the $264 \mathrm{~g} Z \mathrm{Zn}$ per tree treatment (Fig. 1D). $\mathrm{Zn}$ concentration in foliage increased quadratically in both the third $(y=35.4+0.025 x$ $\left.-0.00000165 x^{2} ; \mathrm{R}^{2}=0.72 ; P \leq 0.0001\right)$ and fourth $\left(y=54.9+0.014 x-0.00000128 x^{2}\right.$; $\left.\mathrm{R}^{2}=0.58 ; P \leq 00.0001\right)$ years with maximum foliar $\mathrm{Zn}$ concentration being $\approx 110$ and $95 \mu \mathrm{g} \cdot \mathrm{g}^{-1} \mathrm{dw}$, respectively. The application of a concentrated band of $\mathrm{Zn}$ to drip-irrigated soil has the potential to, directly or indirectly, influence the concentration of metabolically important transition metals in foliage through competitive inhibition of divalent cation uptake by the ever-increasing abundance of soil $\mathrm{Zn}$. Subsequent analysis of Fe, Mn, Co, $\mathrm{Cu}$, and $\mathrm{Ni}$ in fourth growing season foliage found no significant effects of "Zn rate" or "Zn source" on any measured transition element except for Mn. Foliar Mn concentration increased quadratically $(y=165.6+$ $0.061 x-0.00000927 x^{2} ; \mathrm{R}^{2}=0.88 ; P \leq 0.05$ ) as $\mathrm{Zn}$ sulfate applied to the soil increased (Fig. 2). The increase likely indicates that either Mn uptake was positively influenced by acidification of soil by the $\mathrm{S}$ component of the ${ }^{-} \mathrm{SO}_{4}$ anion or because the commercial $\mathrm{Zn}$ sulfate used in this study contained $\mathrm{Mn}$ as a trace contaminate. In either case, foliar Mn probably riskier for micronutrients such as $\mathrm{Zn}$, because of the potential for excessive exposure of a large mass of emitter-associated feeder roots to a potentially toxic concentration of metals.

Both foliar and broadcast $\mathrm{Zn}$ application strategies introduce substantial amounts of metallic $\mathrm{Zn}$ into the orchard environment over a period of several decades. Zinc accumulation in old orchards is such that uptake and physiological availability of $\mathrm{Ni}$ (and possibly $\mathrm{Cu}$ ) are suppressed such that $\mathrm{Zn}$ induced $\mathrm{Ni}$ deficiency became increasingly common in southeastern U.S. orchards, causing "mouse-ear" ("little-leaf") and "orchard replant" maladies (Wood et al., 2004a, 2004b, 2006). Although the soil-banding approach still puts a lot of metallic $\mathrm{Zn}$ into the orchard environment, it is concentrated in a relatively small zone. An alternative approach that potentially increases $\mathrm{Zn}$ use efficiency, mobilization within the plant, and reduces the amount of $\mathrm{Zn}$ going into the orchard environment is a slow-release $\mathrm{Zn}$ material applied to the root collar (Swietlik, 2007). This latter approach merits further investigation for pecan.

\section{Conclusion}

The soil-banding approach to $\mathrm{Zn}$ fertilization demonstrates that $\mathrm{Zn}$ requirements of young pecan trees in drip-irrigated commercial orchards established on certain acidic soils can be satisfied for several years through a single banded application of either $\mathrm{Zn}$ sulfate or $\mathrm{ZnO}$ fertilizer sources. The approach enables tree $\mathrm{Zn}$ needs to be satisfied through root absorption rather than through foliar absorption. Therefore, the root absorption avenue provided by this approach is likely superior to standard foliar Zn application in that it increases the likelihood of $\mathrm{Zn}$ mobilization to nonfoliar organs (e.g., roots) also suffering from $\mathrm{Zn}$ deficiency. The approach is potentially a viable alternative to multiple foliar $\mathrm{Zn}$ applications as is typical of most commercial orchard on acidic soils. It is unknown how many years the single application of soil-applied $\mathrm{Zn}$ will meet tree needs; however, it appears that under moist soil situations, tree $\mathrm{Zn}$ needs will be satisfied for at least 4 years and potentially for several years thereafter as applied $\mathrm{Zn}$ moves deeper into the soil profile with passage of time and more feeder roots penetrate the $\mathrm{Zn}$-enriched zone. Results indicate that because of the usually lower cost, but equal efficacy, $\mathrm{ZnO}$ may potentially prove preferable to $\mathrm{Zn}$ sulfate. Associated cost savings may be small in orchard situations where several spring sprays are required for control of pests; however, savings may be substantial in orchard or yard situations where spring spraying of pests is minimal or absent such as dry springs that make it unnecessary to apply scab disease control sprays until after canopy development is nearly complete. The banding of $\mathrm{Zn}$ onto the soil surface over irrigation lines is a simple, rapid, and efficacious approach to correction of $\mathrm{Zn}$ deficiency. The concentration 
of $\mathrm{Zn}$ above drip irrigation lines does not appear to affect adversely foliar concentrations of other key transition metal micronutrients (i.e., $\mathrm{Fe}, \mathrm{Mn}, \mathrm{Co}, \mathrm{Cu}$, or $\mathrm{Ni}$ ).

\section{Literature Cited}

Alban, A.O. 1955. Preliminary results of treating rosetted pecan trees with chelated zinc. Proc. Amer. Soc. Hort. Sci. 66:28-30.

Alban, A.O. and H.E. Hammar. 1941. Progress report on soil applications of zinc sulfate in the control of rosette of pecan. Proc. Texas Pecan Growers Assn. 21:63-70.

Alban, A.O. and H.E. Hammar. 1944. The effect of pecan rosette from application of zinc sulfate, manure, and sulfur on heavy textured alkaline soils. Proc. Amer. Soc. Hort. Sci. 45:27-32.

Banin, A., J. Navrot, and Y. Ron. 1980. Tree implanted zinc-bentonite paste as a source of slow-release zinc for Delmas pecan. HortScience 15:182-184.

Brooks, O.L. 1964. Yield response of Stuart pecan to zinc sulfate. Proc. Southeastern Pecan Growers Assn. 57:23-25.

Harper, R.E. 1960. A chelate for controlling zinc deficiency in pecan trees. New Mexico Agr. Expt. Sta. Res. Rpt. 36:1-10.

Hunter, J.H. 1965. Effects of lime and zinc on the $\mathrm{pH}$ of the soil, yield of pecans, and zinc content of leaves. Proc. Southeastern Pecan Growers Assn. 58:6-11.

Murphy, L.S. and L.M. Walsh. 1972. Correction of micronutrient deficiencies with fertilizers, $p$. 347-381. In: R.C. Dinauer (ed.). Micronutrients in agriculture. Soil Sci. Soc. Amer., Madison, WI.

O'Barr, R.D. 1989. Pecan nutrition, p. 61-72. In: W.D. Goff, J.R. McVey, and W.S. Gazeway (eds.). Pecan production in the southeast: A guide for growers. Alabama Coop. Ext. Serv. Circ. ANR-459.

Payne, J.A. and D. Sparks. 1982. Zinc level in pecan leaflets from broadcast and band application over a six-year period. HortScience 17:235-236.

Smith, C.L., A.O. Alben, and J.R. Cole. 1934. Progress report of pecan rosette control experiments in Texas. Proc. Texas Pecan Growers Assn. 14:41-46.

Smith, M.W. and J.B. Storey. 1976. The influence of washing procedures on surface removal and leaching of certain elements from pecan leaflets. HortScience 11:50-52.

Smith, M.W., J.B. Storey, and P.N. Westfall. 1979. The influence of two methods of foliar application of zinc and adjuvant solutions on leaflet zinc concentration of pecan trees. HortScience 14:718-719.

Sparks, D. 1976. Zinc nutrition and the pecan-a review. Pecan South 3:304-334.

Sparks, D. 1987. Apparent effect of zinc treatment on the growth rate of pecan production and yield. HortScience 22:899-901.

Sparks, D. and J.A. Payne. 1982. Zinc concentration in pecan leaflets associated with zinc deficiency symptoms. HortScience 17:670671.

Storey, J.B. 2007. Zinc, p. 411-436. In: A.V Barker and D.J. Pilbeam (eds.). Handbook of plant nutrition. Taylor and Francis Group, New York.

Swietlik, D. 1999. Zinc nutrition in horticultural crops. Hort. Rev. (Amer. Soc. Hort. Sci.) 23: 109-178.

Swietlik, D. 2007. A new method of applying zinc to apple plants. Proc. 27th International
Horticultural Congress and Exhibition, Seoul, Korea, 13-20 July. p. 106 (abstr.).

Swietlik, D. and L. Zhang. 1994. Critical zinc activities for sour orange determined with chelator-buffered nutrient solutions. J. Amer. Soc. Hort. Sci. 119:693-701.

Viets, F.G., Jr. 1962. Chemistry and availability of micronutrients in soils. Agr. Food Chem. 10:174-178.

Wadsworth, G. 1970. Absorption and translocation of zinc in pecan trees [Carya illinoensis (Wangenh.) K. Koch]. Texas A \& M University, Masters Thesis.

Walworth, J.L. and A.P. Pond. 2006. Zinc nutrition of pecans growing in alkaline soils. Pecan South 39:14-22.

Wood, B.W. and J.A. Payne. 1987. Comparison of $\mathrm{Zn}$ oxide and $\mathrm{Zn}$ sulfate for correcting severe foliar $\mathrm{Zn}$ deficiency in pecan. HortScience 32:53-56.

Wood, B.W., C.C. Reilly, and A.P. Nyczepir. 2004a. Mouse-ear of pecan: I. Symptomatology and occurrence. HortScience 38:87-94.

Wood, B.W., C.C. Reilly, and A.P. Nyczepir. 2004b. Mouse-ear of pecan: A nickel deficiency. HortScience 39:1238-1242.

Wood, B.W., C.C. Reilly, and A.P. Nyczepir. 2006. Field deficiency of nickel in trees: Symptoms and causes. Acta Hort. 721:83-98.

Worley, R.E., S.A. Harmon, and R.L. Carter. 1972. Effect of zinc sources and methods of application on yield and leaf mineral concentration of pecan, Carya illinoensis. Koch. J. Amer. Soc. Hort. Sci. 97:364-369.

Worley, R.E., R.H. Litrell, and J.D. Dutcher. 1980. A comparison of zinc injection and implantation of zinc capsules for correction of zinc deficiency in pecan trees. J. Arboric. 6:253-257. 